\title{
DENISE STOKLOS E DES-MEDÉIA: A RUPTURA NECESSÁRIA ${ }^{1}$
}

\author{
Luiz Gustavo M. Ribeiro²
}

RESUMO: Uma análise criteriosa da personagem Medéia, na tragédia clássica que leva o nome da protagonista, revela muito de sua concepção, que se dá a partir de uma visão de mundo masculina.

PALAVRAS-CHAVE: Dramaturgia; Personagens Femininos; Desconstrução

Uma análise criteriosa da personagem Medéia, na tragédia clássica que leva o nome da protagonista, revela muito de sua concepção, que se dá a partir de uma visão de mundo masculina. Em Eurípedes, Medéia é uma mulher que se caracteriza por gestos e atitudes de tresloucada paixão, movida pela necessidade de se vingar de uma traição. Sua vida se transforma por Jasão, e a partir do momento em que este não corresponde à dedicação e entrega de Medéia, os fundamentos e a vida desta caem por terra.

Nota-se que a integridade e a completude de Medéia se dão a partir da figura masculina: a Medéia sem Jasão é aniquilada, incompleta, infeliz, amarga, violenta, movida por gestos extremados. Na entrega total e incondicional à causa do amado, ela destrói sua origem, sacrifica seu irmão, abandona sua terra, semeia a discórdia e a morte. Jasão é seu fundamento e sua razão. Por meio dele Medéia cria identidade. Quando não é mais correspondida, sendo preterida por outra mulher, seu drama existencial se agita. Este ponto marca o início da tragédia Medéia, de Eurípedes.

Há diversas investigações e análises acerca da tragédia, bem como de seu autor: alguns estudiosos chegam a afirmar que Eurípedes é um arauto do feminismo, dando voz à mulher de sua época. Todavia, a voz que Eurípedes confere à mulher não deixa de ser uma voz outorgada pelo homem. Construída

\footnotetext{
${ }^{1}$ Comunicação apresentada no XVII Congreso Internacional de Teatro Iberoamericano y Argentino, realizado de 5 a 9 de agosto de 2008 em Buenos Aires. Organizado pelo Instituto de Historia del Arte Argentino y Latinoamericano "Luis Ordaz", Facultad de Filosofía y Letras de la Universidad de Buenos Aires.

${ }^{2}$ Aluno regular do PPGT - Mestrado em Teatro/ CEART-UDESC. Ingresso no PPGT em março de 2008, sob orientação do profa. Dra. Márcia Pompeo Nogueira.
} 
pelo olhar masculino, Medéia é a especulação acerca do que se acreditava ser a mulher: ela não é por e em si, mas para si, projeção e divagação de conceitos estabelecidos por quem ditava e descrevia a ordem.

Ao escrever Des-Medéia, Denise Stoklos desmonumentaliza o clássico e desconstrói o ciclo decadente da trama original, causando uma ruptura com a narrativa de tragédia e morte. Fazendo uma poesia que desmistifica a leitura aviltante acerca do feminino, Stoklos instaura um olhar enriquecedor sobre as relações homem-mulher, e conseqüentemente, sobre as relações humanas.

\section{DES-MEDÉIA: SUBVERSÃO EM PROL DA VIDA}

Em Des-Medéia, Denise Stoklos dá um passo à frente ao optar por uma ação diferente diante da situação de abandono vivenciada por Medéia: "Desatar o nó da tradição de matança aos atos-filhos-sementes, causada pelo desgosto do abandono social-afetivo-espiritual em que nos encontramos no presente, é o tema desta modesta peça de teatro." (STOKLOS, 1995, p.4).

A Medéia de Denise Stoklos incorpora a figura de um contingente humano ao mesmo tempo em que incorpora a figura da mulher. A situação de abandono vivida por Medéia traduz a situação de abandono social vivenciada por todos os excluídos: Medéia também simboliza a humanidade sacrificada por interesses aviltantes e empobrecedores, por ideais injustos, por guerras de individualidades passionais e isoladas.

Stoklos faz uma transposição da tragédia de Eurípedes, dialogando com a realidade brasileira a partir de uma reflexão sobre a tradição na qual se assenta o contexto político. A política brasileira engendra e sedimenta um sistema de injustiça, mentira e degradação, no qual o povo fica à deriva, à mercê de interesses mesquinhos: povo abandonado e sem vínculo, exilado, como Medéia. Assim, Stoklos inspira-se na narrativa grega, fazendo um paralelo entre a situação de abandono vivenciada por Medéia e a vivenciada pelos brasileiros: Medéiabrasileiros traída por Jasão-políticos.

Todavia, na peça de Stoklos há um novo elemento: Medéia subverte a narrativa clássica, e interrompe o ciclo de mortes e destruições. Não mais gestos de vingança, mas de aproximação. Medéia opta pelos caminhos do amor e da 
confiança, transformando a dor em aprendizado. Já no início da peça, o Coro revela:

E mais uma: Medéia não é de carne e osso como nossos criminosos: é apenas um mito, criado para simbolizar a espelhar esse lado escuro da natureza humana, para que possamos refletir sobre ele e transformálo. Que a nossa Medéia, portanto, se desmedéie, se transforme, evolua, remedie-se o mito já, que se remende essa característica simbólica do perdurável escuro da natureza humana. Que aqui essa abordagem ao mito da paixão seja subvertida em um grito de: Remendéia, alma brasileira! Desmedéie-se! Para que no final de nossa própria história, como Medéia, sim, alcemos vôo na nossa carruagem guiada pelo sol, só que desta vez não num vôo glorificado pela derrota na depressão, mas pela vitória efusiva no amor. Nem que isso se chame utopia, que pra nós, essas almas em processo desmedéico diário rumo à eternidade do amor, pra nós utopia na verdade rima bem com mudança agora, já e todo o dia. (STOKLOS, 1995:9)

A peça de Stoklos se caracteriza pelo diálogo de Medéia consigo mesma: reflexão sobre si e suas atitudes para com Jasão e o mundo. Mesmo preterida, transita pela situação com autonomia, optando pelo caminho sem guerra e conflito sujos. Dá um salto qualitativo, rompendo com os comportamentos narrados na tragédia clássica. Em Stoklos, há somente a presença de Medéia e do Coro, que narra a estória daquela e sua atitude de reflexão ponderada. Medéia, sentindo-se abandonada, percebe a possibilidade de aprender com a dor e transformar, resignificando suas experiências. Sua trajetória é rumo à integração das partes dilaceradas. O Coro narra o abandono:

Medéia está aqui surpreendida sem nenhuma aliança, com a
esperança. Mas querendo muito ouvir o chamamento inerente de
pertencer. Ela está sem nenhuma ligação, nem a uma ideologia, nem a
uma idéia nobre de pátria, nem à sua memória, a seu passado, seu
futuro, nem à Terra, nem a si mesma. Nenhum presente. Só. Como
nós. (STOKLOS, 1995:10)

E prossegue: "Compartilharemos apenas alguns minutos da vida de Medéia em sua miséria, em sua jaula ancestral da dor, que fede esterco e palha." (STOKLOS, 1995:11). Miséria e dor que apontam para a possibilidade de se reerguer e reconstruir. Medéia relembra o "paraíso" no qual vivia com Jasão, em unidade com o amado: 
Ah, quem me dera a paz esporrada de nossos lençóis, após. Água voltada à pedra lisa, remanescente de costa tranqüila seu dorso. Calmaria de meu fogo seu beijo na minha boca, pedra, pedra, pedra lisa em que se banha minha água e faz áspera apenas a distância da água e da praia, das dunas e do céu, do trem e da estação. Meu desejo e sua cama nova. Nova, nova, novamente a imagem do corpo de meu capitão de músculos dourados e os braços, carnais guindastes que me elevavam no topo absoluto de nosso orgasmo quase dor, quase desmaio, real passagem para o futuro. Eu via na máquina de nosso amor o futuro a cada instante sendo conquistado por nós, arrebanhado do nada. Tirávamos o nosso presente do que ainda não era e o fazíamos ser, na travessia dos orgasmos. Eu vivenciava o infinito. Eu conhecia o infinito em sua analítica dimensão. (STOKLOS, 1995:12)

Plenitude gozosa de vida a dois, paraíso do compartilhar interrompido pela traição, Medéia desabafa sua escuridão, o "aborto de vida" sofrido inesperadamente:

Na falta de tê-lo, Jasão você me faz planar debruçada no vácuo. Sem vê-lo reparte-se o tempo, distanciando-o. Distante, a partida não pedida. Perde-se na dita distância cada vez mais o tempo. [...] Agora existe apenas o ardor de inferno inútil de sua ausência, o ardor dos não-atos na prateleira da memória, esses fetos não nascidos, conservados em álcool, incompletos fatos. A angústia de um laboratório interno com prateleiras descomunais repletas de fetos em álcool. Mantidos em limbo, abandonados, dormindo sós toda noite e dia. Mais soturno é de dia quando a claridade bate nas prateleiras e o silêncio e a falta de vida dentro dos vidros grita estala como um graveto úmido no fogo. (STOKLOS, 1995:12, 13, 15)

Medéia olha sua dor de frente, no intuito de assimilá-la e compreendê-la. Mergulha na dor, quer superá-la. Ciente de seu conflito, não nega a dor. O Coro faz um chamamento ao olhar aprimorado e equilibrado, realizando uma importante costura com o tema da conduta política e moral, através da analogia com a idílica união amorosa:

Bom seria... Que pena que nossa felicidade sempre começa com: "bom seria", jamais com "está sendo". [...] Bom seria se os cargos políticos se elegessem pela intuição geral, naturalmente. O intuitivo tribal se estabeleceria como pleno soberano. Assim como um casal apaixonado se escolhe: pela atração da paixão, a atração do cuidado, da confiança. Que se distribuíssem os papéis numa sociedade como o casal apaixonado distribui entre si qual lugar ocupará na cama: pela inércia dos carinhos - as carícias é que acabam por empurrar um corpo mais para cá, levam o outro mais para ali. Que em tudo assim 
fosse. Que assim seja amém. Amem-se, parece-nos dizer a única oração subordinada à vida. Morrer poderia ser completar a proposta. Só então, não antes. [...] Um dia somente: hoje, é necessário para subverter a ordem. Um dia a mais somente, hoje, e poderá coalhar-se a Via Láctea ou poderá hoje destronar-se a oligarquia. Tudo de ontem pude mudar neste hoje, hoje. [...] Optaremos pelo resgate do tempo perdido já, hoje. Pois afinal, todos reconhecemos que viver é feito nada mais nada menos que, do desempenho da nossa capacidade de maratonistas, de quão longe delegaremos no final de tudo, esse bastão sagrado do espírito ao próximo. (STOKLOS, 1995:16, 17)

A convocação para a ação e a iniciativa é no tempo presente: caminhar em busca da transformação requer dar o primeiro passo. Perceber no presente o aceno do universo, atentos para a necessidade de mudanças, para a abertura e a ruptura. O maratonista transfere o bastão ao próximo, que é extensão de si. A opção pela vida se manifesta, e a compreensão da morte no ciclo vital se coloca: complemento da proposta. Medéia tem então uma percepção: a presença da "verdade", que supera as contradições e dialéticas para se firmar, plena e irredutível. A verdade é vida, e não se escamoteia nos gestos premeditados e intenções mascaradas. Medéia sabe que seus gestos de fúria não impedirão, em última instância, a "verdade" mesma das coisas. Medéia diz: "Mas de cima para baixo e de baixo para cima a verdade permanece ultimato irreversível na vida." (STOKLOS, 1995:18)

O Coro atenta também para o comportamento de sábia assumido por Medéia, a qual não mais cede aos ímpetos de furor e vingança, mas adota gestos comedidos e ponderados durante o confronto: "Lutadora, como os mestres orientais marciais, não conta com a primária surpresa do golpe, o bote da serpente para o ataque ou defesa, mas com o desmanchar da força do golpe no rebatê-lo, em que a própria força do agressor retorne desarmamento." (STOKLOS, 1995:21)

Medéia também canta o amor a Jasão de forma mais amadurecida, sem a doentia fixação da tragédia clássica. O amor sem manipulação e fantasia, mas da compreensão:

Você já veio para mim formado, com marcas e passado, se eu quero amar você todo, convém que tudo seu eu veja como o que deve ser respeitado. Ora, se eu quero sair com você de braço dado, não posso enlaçar o pulso alheio, há de ser só o seu punho inteiro, verdadeiro. E 
cuidar que as mãos dadas conduzam-nos pelas portas das bibliotecas antes fechadas a duas mãos apenas. Pois quatro forçam trincos e chaves a brincos a claves, a manhas e a senhas. (STOKLOS, 1995:24)

Medéia opta pela manutenção da vida e pela interrupção dos gestos movidos pela vingança. Nega a morte intencional, reconhece sua dor, mas não se transforma nela. Tem consciência da transitoriedade da situação, de que este não prosperará, pois a vida sempre acena com novas possibilidades: "Não imolarei morte nenhuma por você, nenhum sacrifício ritual, a causa não merece. Há muito a se fazer adiante. Saiba que você me magoou..." (STOKLOS, 1995:25)

Um salto qualitativo na trajetória de Medéia, não mais figura abandonada solitária e decadente, mas uma mulher integrada e consciente, na busca pela afirmação da vida e da humanidade. Assim, o Coro estabelece uma nova reflexão acerca do referencial clássico, utilizando-o para propiciar uma indagação pertinente acerca da realidade que assola o Brasil, convocando à subversão desta realidade:

O autor grego Eurípedes escreveu a primeira peça sobre Medéia há muitos anos. Medéia nasceu para o teatro em 431 antes de Cristo. Contando regressivamente os minutos que nos restam até o ano dois mil falta pouco para completar muito tempo que assistimos a tragédias sobre traições enquanto traímos incansavelmente aprimoradamente através dos séculos todas as causas humanas. Neste berçário de ventre de Medéia que é este Brasil nossas aspirações são cesarianas carpideiras que choram a possível reafirmação da morte. [...] Nossa transmissão do mito se desconstruirá. Que todo esse fogo apaixonado de Medéia seja nosso impulso para frente e não para trás. [...] Nossa Medéia a brasileira há de encontrar outro destino. Pois nós brasileiros queremos uma nova Medéia, uma que se desfaça do ódio destruidor para uma reflexão positiva sobre o momento em que também estamos sem nenhum vínculo: como ela. Sem vínculo com o sentido de pátria, sem vínculo com irmãos, com nossos vizinhos, sem vínculos com nossos filhos: o nosso futuro, os nossos traços, a nossa herança. Então, como temos repetido destruições, nunca é demais abordar o tema, mas desta vez subvertendo-o. Que no nosso Brasil não mais se repitam as Medéias. Não mais assassinemos nossos filhos diariamente - os nossos sonhos, nossos frutos (nossa originalidade). Nem nossa pátria - a casa da ética (a convivência dentro de justiça). Nem nossos irmãos (todo conterrâneo, todo contemporâneo). Nem nossos rivais (a competição é sempre base de capitalismo criminoso). Nem os reis traidores (o acerto há de ser sem conchavo mas definitivamente sem contemporização, mas com mudança, para a paz). (STOKLOS, 1995:26, 29, 30) 
A fala do Coro é um chamamento à mudança dos valores apregoados pela sociedade ausente de si, uma advertência ao descontrole de Medéia-povo, que sucumbe mediante a dor, semeando a morte em vida. O Coro alerta para a necessária mudança de rumo de tal enredo. Ao que Medéia corresponde, conscientemente:

Nossos frutos/filhos/atos nasceram de nós dois, mas o leite que os alimentou veio do peito único que você quebrou. Foram acalentados com canções de fé que você não mais professa e rufião chutou-as com o pé com pressa. Você não foi o que agora eles perdem, então assim nada perdem. [...] Destrono-te Jasão do direito de permanecer em mim, que é sobre o qual temos autoria: a liberdade de escolher o repertório que me ocupa. Este, você perdeu. Nós aqui de outro lado não, nada perdemos. Não podemos perder o que nunca foi nosso. Em você está o abandono, a traição, a deslealdade, a confirmação do establishment. Saio desta história sem matar ninguém, nem sequer de um parpois descubro que nunca tive um. [...] Meus atos/filhos/sementes foram obras de sonho, e assim, para sempre os embalarei. (STOKLOS, 1995:30, 31)

Medéia, ao destronar Jasão de seu lugar, está afirmando sua identidade no mundo, e está reconstruindo sua história de maneira salutar. Ela reconhece que sua situação a faz sofrer, mas vive a dor na medida necessária: não sucumbe e nem desfalece. Medéia sabe que deve evoluir. Transmutou a dor em oportunidade de aprendizado e crescimento. O Coro celebra a transformação:

Até o final da clássica peça, Medéia estaria comprometida com vários assassinatos. Mas só um afinal é que sobrevive aos microfilmes depois da irradiação final da Terra: a perda do vínculo com sua natureza humana, a quebra do anel, o espelho espatifado, a intensidade rompida, a entrega excessiva. Antes foi o pai e o irmão que ela rasgou do cenário da casa dela. Mas não matou filhos neste espetáculo. Isto foi por fim invertido. Sua natureza há de ser salva. Também não esteve aqui cozinhando nem costurando. Ocupou-se de transformar. Tal como ela, o mito, merecemos desfazer já todo malfeito, fazê-lo em novo jeito: bem. Agindo para que, no final da nossa história, sim, como Medéia alcemos vôo numa carruagem guiada pelo sol porém rumo à eternidade do amor, nem que isso se chame utopia que para nós quer dizer mudança agora, já e todo o dia... (STOKLOS, 1995:31)

Medéia interrompeu o gesto brusco e irrefletido, pois se integrou. Descobriu que é capaz: mulher autônoma existe sem Jasão, pode caminhar com as próprias pernas e escrever a própria história. Em sua transmutação, redimida, alquimizou. 
Medéia é uma heroína em sua potencialidade, é completa e consciente: Medéiamulher-humana!

Referências Bibliográficas:

EURÍPEDES. Medéia. Trad. Millôr Fernandes. Rio de Janeiro: Civilização Brasileira, 2004.

STOKLOS, Denise. Des-Medéia. São Paulo: Denise Stoklos Produções Artísticas Ltda., 1995. 